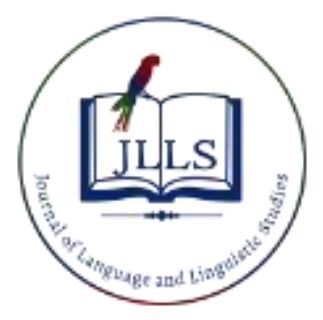

Available online at www.jlls.org

JOURNAL OF LANGUAGE AND LINGUISTIC STUDIES

ISSN: $1305-578 \mathrm{X}$

Journal of Language and Linguistic Studies, 16(2), 729-737; 2020

\title{
Translating culture in children's literature: A case study on the Turkish translation of Letters from Father Christmas
}

\author{
Gökçen Hastürkoğlu a \\ APA Citation: \\ ${ }^{a}$ Atllim University, Ankara, Turkey \\ Hastürkoğlu, G. (2020). Translating culture in children's literature: A case study on the Turkish translation of Letters from Father Christmas. \\ Journal of Language and Linguistic Studies, 16(2), 729-737. \\ Submission Date:26/11/2019 \\ Acceptance Date:07/04/2020
}

\begin{abstract}
Translation has been considered as a cross-cultural act comprising the transference of the cultural signs, rather than only finding the equivalence of linguistic patterns in the target text. As bridge-builders between different cultures, translators assume a very significant role in order to achieve the most appropriate cognitive, cultural, stylistic, and linguistic equivalence in the target system. This role becomes more challenging and problematic when the target audience are children. By emphasizing the difficulties in translating children's literature and the required strategies, the present study examines the Turkish translation of culturally-bound words and expressions in Tolkien's Letters From Father Christmas. Within the framework of Lawrence Venuti's concepts of domestication and foreignization, and Klingberg's scheme of cultural context adaptation categories, this study analysed the translator's strategies and decisions and discussed whether the translator successfully conveys the same impression in the target audience in a context which is foreign to the Turkish culture and children in particular.
\end{abstract}

(C) 2020 JLLS and the Authors - Published by JLLS.

Keywords: culture-specific items; domestication; foreignization; translation of children's literature; Tolkien; Letters from Father Christmas

\section{Introduction}

Over the past century, societies have been interacting more increasingly with each other, which has brought about the exchange of cultures with the general acceptance of the uniqueness of each one. As for Duranti (1997), culture is "something learned, transmitted, passed down from one generation to the next, through human actions, often in the form of face-to-face interaction, and, of course, through linguistic communication" (p. 24). Earlier than this definition, Newmark (1988) proposed that culture is "the way of life and its manifestations that are peculiar to a community that uses a particular language as its means of expression" (p. 94). These statements reaffirm the fact that language is an integral part of culture, and that each language has its own cultural features.

As the bridge-builders between different cultures, civilizations, and languages, translators assume a very crucial role in the transmission of culture among societies. Being fully aware of the uniqueness of each culture and the variations among the culture-specific words and expressions in the source and target 
culture, they try to achieve equivalence in target texts in order to make readers comprehend and get involved in the discourse. In particular, the act of cultural translation becomes more challenging when children are the readers; this is because they have a more limited world knowledge and linguistic abilities compared to adults. They are also the group which has the greatest need for reading for intellectual, linguistic, social, and cultural development.

Never has there been a greater demand to be able to read books from other areas of the world [...] children need to read the best literature other countries have to offer. We must meet this challenge by respecting and providing the best in translations or they will be cheated out of part of their global heritage... (in Hunt and Bannister Ray, 2004, p. 521)

In this respect, it is the translators who assume the role of closing the distance between children and cultures unfamiliar to them. As Lindgren asserted "children have a marvellous ability to re-experience the most alien and distant things and circumstances if a good translator is there to help them."

The question of how translators can help children experience different cultures has been raised dominantly since the 1970s, when translation scholars began to appreciate the importance of translation of children's literature in terms of cultural, educational, intellectual, social, linguistic, and cognitive development of children, and started to develop strategies and methods for overcoming the problems encountered while translating such texts. Since then, translators have been standing at the two poles, while being categorized choosing to be target-oriented by taking into account the norms of the target culture and those who choose to be source-oriented and, thus, stick to the source culture norms. Oittinen (2000), for instance, emphasized that translators "need to adapt their texts according to the presumptive readers" (p. 78), and thus, insisted on 'translating for children' rather than using the term 'translation of children's literature. Puurtinen (1998) also believed in the necessity of taking the linguistic capabilities of children, and recommended translators to create comprehensible and readable target texts (p. 2). As pointed out by Reiss, translators should make deviations from the source text due to three reasons: (1) children's imperfect linguistic competence, (2) avoidance of breaking taboos which educationally minded adults might want to uphold, (3) childrens' limited world knowledge (qtd. in Tabbert, 2002, p. 314). Such scholars and translators have a tendency to use adaptation strategies while translating texts for children.

On the other hand, it is a fact that children have the chance to travel through unknown countries and experience different cultures with the help of the translations of their literature. That is why some scholars, such as Batchelder, believed that "children of one country who come to know the books and stories of many countries have made a beginning toward international understanding" (qtd in Metcalf, 2003, p. 324). By reading translated texts, they can gain the opportunity to bring the most distant to the nearby and learn about new traditions and cultures, and experience different lifestyles. Thus, while translating such texts, foreignization strategies can be adopted in order to expose young readers to the new, foreign, and different.

Being one of the most challenging aspects in children's literature, culturally-bound words and expressions have been focused on by researchers through case studies investigating the translations in different language pairs. For instance, Erten (2016) studied the Turkish translations of Roald Dahl's Charlie and the Chocolate Factory by focusing on the translator's handling of the culture-bound features. She concluded that the norm of acceptability should be taken into consideration when dealing with children's literature. Persson (2015) revealed the problems and difficulties encountered when translating culture-specific items in the selected extracts from Australian and New Zealand colonial and post-colonial children's literature into Swedish. Pavlov (2014) investigated the strategies adopted in the French translations of the Harry Potter series by J.K. Rowling and two stories by Astrid Lindgren. 
Based on this background, the present study intends to analyse the translator's strategies and decisions when applying Klingberg's scheme of cultural context adaptation categories to translate Letters From Father Christmas within the framework of Lawrence Venuti's concepts of domestication and foreignization. It is further discussed whether the translator, Leyla Roksan Çağlar, can successfully create the same meanings and effects on children in her translation of the work into Turkish. Within this framework, this study mainly attempts to find an answer to the following research questions: How are the culture-specific items in Letters From Father Christmas translated into Turkish in order to reproduce the same effects as in the source text? Which one of the two macro translation strategies, domestication and foreignization, is adopted more frequently in translating culture-specific items?

\subsection{Theoretical Background}

\subsubsection{Venuti's Domestication and Foreignization}

The terms 'domestication' and 'foreignization' were coined in the 1990s by the American translation theorist, Lawrence Venuti, and they have been used ever since in both translation practices and theories. Domestication, as Venuti (1988) explained, refers to translation strategies which "conform to values currently dominating target-language culture, taking a conservative and openly assimilationist approach to the foreign, appropriating it to support domestic canons, publishing trends, political alignments" (p. 242). However, foreignization "entails choosing a foreign text and developing a translation method along lines which are excluded by dominant values in the target language" (ibid.). The former is also defined as "an ethnocentric reduction of the foreign text to target-language cultural values, bring the author back home", while the latter is "an ethnodeviant pressure on those (cultural) values to register the linguistic and cultural difference of the foreign text, sending the reader abroad" (Venuti, 1995, p. 20). In other words, domestication refers to the type of translation in which the strangeness of the foreign text is minimized by the translator for the target group through a fluent and transparent style; whereas, foreignization designates the production of a target text which deliberately retains foreignness of the source text (Shuttleworth \& Cowie, 1997, p. 59). That is why, while reading a work in children's literature translated by adopting the foreignization strategy, a child often comes across cultural references that she/he is unfamiliar with. However, while reading a work translated with the domestication approach, the child can sense that it is written in his/her mother-tongue.

The dilemma whether to adopt foreignization or domestication approach is also emphasized by Scheleirmacher:

Translators may assume two different positions and on this basis they will employ a specific translation strategy. On the one hand they may think that reading a book rich in culture-specific elements enables children to learn and enlarge their knowledge of the world, or on the other hand they may believe that children cannot deal with a foreign culture because they do not yet possess adequate interpretative and cognitive capacities. (cited in Wolf et al., 2010, p. 425)

Thus, each translator has a tendency to use one of these approaches by taking into consideration many issues concerning children. Nevertheless, rather than being on the side of one of these poles, compromising these two distinct categories while translating children's literature is also recommended by some of the scholars and researchers.

... any translation both foreignizes and domesticates, not only in different places respectively but even in the same place and at different levels (lexical, phonological, syntactic, typographical etc.) in varying degrees. The "switch" model (domestication versus foreignization) should be replaced by the "dimmer" model (domestication and foreignization) in varying degrees. (Peeters 2005, 146-147) 


\subsubsection{Klingberg's scheme of cultural context adaptation categories and translation strategies}

Klingberg categorized the cultural-specific items that can be encountered in children's literature; these are "literary references; foreign languages in the source text; references to mythology and popular belief; historical, religious and political background; building and home furnishings, food; customs and practices, play and games; flora and fauna; personal names, titles, names of domestic animals, names of objects; geographical names; and weights and measures" (Klingberg, 1986, pp. 17-18). These categories are regarded as the main items which translators find problematic and challenging in translating for children.

In order to overcome these difficulties, Klingberg also provided nine strategies, namely "added explanation, rewording, explanatory translation, explanation outside the text, substitution of an equivalent in the culture of the TL, substitution of a rough equivalent in the culture of the TL, simplification, deletion, and localization" (p. 18). It is obvious that the first four strategies are close to the foreignization approach and they leave the culture-specific items close to the source text, while the rest is achieved through the domestication approach which makes the culture-specific items familiar for the target audience. However, deletion and localization can be considered as extreme modifications creating very significant losses and gains for the target text.

\section{Method}

\subsection{Selection of the material}

The corpus drawn upon in this study is J. R. R. Tolkien's Letters From Father Christmas (1995) and its Turkish translation Noel Babadan Mektuplar (2005) made by 16-year-old Leyla Roksan Çağlar. Letters From Father Christmas is a collection of letters that Tolkien sends to his children every year between 1920 and 1942. Each page is also illustrated by himself with scenes from the North Pole. Through the letters written by Father Christmas, the reader has the chance to experience the Christmas mythology which is extended by Tolkien including elves, goblins, wars, the best-friend North Polar Bear, and a number of creatures revealing his rich imagination.

The reason for selecting this work for analysis is that the novel is set in Christmas, which is originally distant from the Turkish culture, which merely celebrates the new year at the same time with many other countries on December $31^{\text {st }}$. Moreover, Çağlar emphasizes in the translator's notes at the end of the book that she wanted to make the novel as much Turkish as possible. This effort can be observed, among others, in her translation of the children's and Father Christmas' names (Tolkien, 2005). Although Çağlar seems to have adopted a domestication approach while translating the novel, the present study aims to further examine her strategies adopted by her and discuss whether she achieved cognitive and cultural equivalence using the stated approach in such a foreign context for the Turkish youth.

\subsection{Data analysis}

This study employs a descriptive design with a qualitative approach in analysing and demonstrating the obtained data, which are the culture-specific items, translation approaches and strategies observed in the Turkish translation of Letters From Father Christmas. Initially, both the source and the target text are read thoroughly in order to find culture-specific items. Then, each item is classified in accordance with Klingberg's categorization. Next, through comparative analysis, whether the translator adopts domestication or foreignization approach is revealed by discussing the strategies used and the possible reasons behind them. Some examples of each type of culture-specific items found in the source text are provided to support the discussion. 


\section{Results and Discussion}

\subsection{Data analysis}

In terms of the translating names, Klingberg believed "it is reasonable to demand that personal names, belonging to everyday language and without any special meanings that the readers have to understand, should not be altered when a foreign culture is introduced by way of translation" (1986, p. 43).

It can be observed that Klingberg's suggestions do not always apply to the translation of personal names in The Letters From Father Christmas. Instead, there is a marriage of two approaches, domestication and foreignization, as in some cases the names are changed entirely. For example, those of Father Christmas' children, John, Michael, Christopher, and Priscilla are translated differently in almost every letter. For instance, John is translated as 'John' in one of the letters by adopting foreignization, but it is also translated as 'Can' (p. 66, p. 74) in a later letter through domestication. Likewise, Michael is transferred to the target text most of the time as 'Michael', but there are some letters in which 'Michael' is translated as 'Mayk11'. 'Christopher' is, in some instances, transferred as 'Christopher' or 'Chris', and also translated as 'Kris' which foreignization. However, 'Priscilla' is always kept as 'Priscilla'.

Klingberg sometimes supports changing a name even if it is used in everyday language if there is a word play in the name. For instance, When Michael is called as 'Michaelmas' in the source text, it is translated as 'Moel'. As the translator states in the translator's notes, she aims to imitate Tolkien's wordplays in such cases.

'Father Christmas' is referred in a number ways in the original work; thus, these names are translated using different strategies, some through the domestication approach and others through the foreignization approach. In one of the letters, he is named as 'Father Nicholas Christmas', and it is translated as 'Noel Baba' by deleting 'Nicholas', 'Noel Baba Nikola', 'Noel Niko Baba', 'Hıristo Nikola Baba', 'Nikol Baba', and 'Krisdos Baba', in all of which the translator adopted a foreignization approach and tried to preserve Tolkien's word play.

Such examples in the translation of names reveal the fact that the translator adopts domestication for the sake of making the source text sound more Turkish, as claimed in the translator's notes. It can also be observed that, she adopts the foreignization approach more than domestication in terms of the translation of names.

\subsection{Translation of weights and measures}

In terms of the translation of weights and measures, Çağlar does not apply only one approach. For instance, '200 miles' is translated as '200 mil' by using a foreignization strategy in one of the letters, while 'hundreds of miles' is translated as 'yüzlerce kilometre' through the domestication approach, by converting miles to kilometres in another letter.

\subsection{Translation of food}

As for the translation of food terms, instead of the adoption of the deleting strategy or replacing them with food terms from the target culture, Klingberg suggests added explanation strategy to provide children with a better understanding of the source culture and raise their interests in the foreign culture (p. 36).

As observed in this study, the translator does not use such a strategy. For instance, although 'plum pudding', which is also called as 'Christmas pudding' or 'figgy pudding', is a food item that is 
traditionally consumed at Christmas dinners, it is domesticated and replaced with a food item 'erikli muhallebi'. Again, in another sentence, "He had eaten two whole puddings raw" (Tolkien, p. 44), the same term, pudding, is translated as 'tatlı', "Bütün tatlıları çiğ çiğ yemiş" (Tolkien, p. 44) by using absolute universalism strategy, instead of using 'pudding'. The point is that 'puding' is a loan word used very commonly in the Turkish culture. Therefore, the term 'puding' can be used in such translations, as it is very probable for the target reader to have prior knowledge of this food item.

\subsection{Translation of play and games}

As for the translation of play and games, Klingberg (ibid: 38-40) recommends "added explanation, explanatory translation, rewording and even explanation outside the text, but not deletion or replacement by an equivalent from the target culture". In other words, he supports foreignization approaches for these culture-specific items.

Çağlar does not adopt the techniques Klingberg suggests for translating plays and games in her translation. For instance, 'Snapdragons' is translated as 'parmakla ip çevirmece'; however, the translator could not achieve creating the same impact on the target reader, as children in Turkish culture do not have a tradition of playing snapdragons at Christmas. As snapdragons is a popular game played during the winter, particularly on the Christmas Eve, the cultural equivalence could only be achieved by using 'tombala' in the target text which is a traditional game played on new year eves. Yet, the translator does not use such a domestication strategy here by providing the cultural equivalence in the target culture, and, instead, adopts an explanatory approach.

The other culture-specific play and game is available in this sentence, "I send you lots of love (and lots for Michael too) and Lotts Bricks (too) which are called that because there are lots more for you to have next year if you let me know in good time). I think they are prettier and stronger and tidier than Picabrix." (Tolkien, p. 8), which is translated as "Hepinize çok çok sevgiler, Michael'a da çok çok sevgiler. Çok çok oyun taşı da gönderiyorum. Gelecek yıl bana vaktinde haber verirseniz size bunlardan daha çok gönderirim. Bunlar öbür taşlardan daha güzel ve daha sağlam. Umarım sizin de hoşunuza gidecek." (p. 8). 'Picabrix', considered as the early version of 'Lego', is a wooden block construction set system ranging from very simple designs to the most complex models. Similarly, 'Lotts Bricks' are stone-blocks in rectangular and wedge shapes, again originated in England, as early as 1918. For the translation of these two games, 'oyun taşı' is used without any further descriptions.

\subsection{Translation of customs and practices}

The tradition of hanging the Christmas stocking with the belief that Santa Claus can fill the stocking if people hang their stockings by their bedposts or on the Christmas tree while they are sleeping, is translated by adopting different approaches in this work. In one instance, 'filling of the stockings' on Christmas is translated as 'Noel Babanın getirdiği hediyeler' (the presents that Father Christmas brought), by deleting the word 'stocking', while in the other example, it is translated as 'hediye atmam gereken baca' (the chimney through which I have to throw the present), by using the technique of substitution of a rough equivalent in the target language. However, 'stocking' is translated as 'hediye torbası çorap' (the present bag stocking) and 'ipe hediye torbası asmak' (to hang the present bag to the rope) five times by using literal translation strategy. However, it should be noted that children of modern times know such traditions as a result of cartoons and movies they watch, or from the books they read, or from the images they see on the Web. Therefore, they cannot be regarded as aliens towards such traditions. 


\subsection{Translation of historical, religious and political background}

The Turkish translation, Noel Babadan Mektuplar, promoted hot discussions in terms of translators' visibility and invisibility issues when it was published in 2006. In terms of the translation of terms related to historical, religious and political background, Çağlar omitted the year '1453' two times from the original letters that Father Christmas sent on 23 December 1932 and 21 December 1933. The year 1453 is when the Byzantine Empire's capital is captured by the Ottoman Empire. Çağlar argues in the translator's notes that the year 1453 represents the fall of Constantinople (Istanbul) in the Turkish society emphasizing that what Tolkien intended to do is religious prejudice which is repeated inconsiderately (Tolkien, 2005).

Still under this category, 'Boxing Day' is translated as 'Paketleme günü' three times by adopting the direct translation strategy which yielded unacceptable translation. Boxing day is the day after Christmas (26th December) which "was traditionally a day off for servants, and the day when they received a special Christmas box from their masters" (BBC, 2018). In some European countries, this day is celebrated and considered as the second Christmas day with a religious tone to it, it is "celebrated as Saint Stephen's Day in Ireland and the Catalonia region of Spain" (ibid.). It is obvious that there is no relationship between the tradition of 'Boxing Day' and 'Paketleme Günü', which is a non-existant term and, as such, makes no sense at all in the target culture.

As another instance for this category, 'All Saints' Day' is a term with religious background and is translated as 'Azizler Yortusu' through finding its equivalent in the target culture. All Saints' Day is celebrated by the Roman Catholic Church and it is also known in Turkish culture.

\subsection{Translation of geographical names}

In terms of the translation of geographical names, Klingberg insisted on retaining these names as they are in the source language. When standard forms are available in the target language these forms should be used. However, when there is no specific form in the target language, the translator is not free to create one (pp. 50-51). For instance, 'Nova Scotia' is translated as 'Yeni İskoçya' which is used in Turkish using direct translation. Nevertheless, 'Oxford' is translated as 'Oksfor Boksfor', a non-existent location, although Oxford is used as it is in Turkish as well. The translator seems to intend to compensate for the word plays in other parts as Tolkien does occasionally throughout the original text.

\section{Conclusions}

This study is an attempt to demonstrate the tendency of the translator of Letters From Father Christmas in terms of adopting foreignization and domestication strategies within the context of Christmas, whose traditions and customs are alien for the target culture's children.

As an answer to the research questions of the study, it is clear from the data analysis that both domestication and foreignization are utilized by the translator. Although the most common choice of translation procedure depends on what type of culture specific item is translated, it is observed that the cultural items in the source text are often foreignized which is contrary to the translator's assertions in her notes at the end of the novel. Also, the translator claims to intend to make the text sound more Turkish, there are many instances where she does otherwise- that is, she foreignizes the culture specific items.

There is no doubt that both strategies are effective in translating children's literature. It is not appropriate to state that a translator should adopt only one of them to achieve equivalence, and it is difficult to follow one translation strategy consistently. The sharp division between foreignization and domestication in translation is too categorical. It should be taken into consideration that readability 
cannot only be achieved through domestication strategies, as the children have a great capacity to learn about new cultures. Providing young readers with new educational, social, and cultural experiences helps broaden their visions and can be the main reason for reading non-domestic work.

This study could serve as an impetus for more thorough comparative analysis of translations for children readers in order to observe the strategies the translators tend to adopt more dominantly and provide a clearer picture for the requirement of compromising both strategies.

\section{Ethics Committee Approval}

The author(s) confirm(s) that the study does not need ethics committee approval according to the research integrity rules in their country. (Date of Confirmation: June 02, 2020)

\section{References}

Berman A. (2004). Translation and the trials of the foreign. In L. Venuti (Ed.), The translation studies reader (pp. 276-289). London: Routledge.

Duranti, A. (1997). Linguistic anthropology. Cambridge: Cambridge University Press.

Erten, A. (2016). Translating culture-bound features in children's literature. Humanities and social sciences review. 5(2), 67-72.

Hunt, P. \& Bannister Ray, S.G. (2004). International companion encyclopaedia of children's literature. London: Routledge.

Klingberg, G. (1986). Children's fiction in the hands of the translators. Lund, Sweden: C.W.K Gleerup.

Lathey, G. (2006). The Translation of children's literature: A reader. Clevedon: Multilingual Matters.

Newmark, P. (1988). Textbook of translation. Oxford: Pergamon Press.

Oittinen, R. (2000). Translating for children. New York, NY: Garland Publishing.

Peeters, J. (2005). Localizing and globalizing trends in language through the looking glass. In M. Sidiropoulou (Eds.), Identity and difference. Translation shaping culture (pp. 129-149). Bern: Peter Lang.

Persson, U. (2015). Culture-specific items. Translation procedures for a text about Australian and New Zealand Children's Literature.(Unpublished MA Thesis), Linnaeus University.

Puurtinen, T. (1998). Syntax, readability and ideology in children's literature. Meta, 43(4), 524-533. DOI: $10.7202 / 003879$ ar.

Shuttleworth, M. \& Cowie, M. (1997). Dictionary of translation studies. Manchester, UK: St Jerome Publishing.

Tabbert, R. (2002). Approaches to the translation of children's literature: A review of critical studies since 1960. Target, 14(2), 303-351. DOI: 10.1075/target.14.2.06tab.

Tolkien, J. R. R. (1995). Letters from Father Christmas. London: Collins Children's Books.

Tolkien, J. R. R. (2005). Noel Baba'dan Mektuplar. (L. R. Çağlar, Trans.). Istanbul: Okuyan Us Publishing.

Venuti, L. (1995). The Translator's invisibility: A history of translation. London \& New York: Routledge. 
Venuti, L., (1998). Strategies of translation. In M. Baker (Eds.), Routledge encyclopedia of translation studies (pp: 240-244). London: Routledge.

Why is it called 'Boxing Day'. (2018). Retrieved on September 23, 2019 from https://www.bbc.co.uk/newsround/46454700

Wolf, S., et al. (2010). Handbook of research on children's and young adult literature. New York: Routledge.

\title{
Çocuk edebiyatında kültürü çevirmek: Letters From Father Christmas'ın
}

\author{
Türkçe çevirisi üzerine bir çalışma
}

\section{$\ddot{O} \mathbf{z}$}

Çeviri, dilbilimsel unsurların kaynak dilden hedef dile aktarımından ziyade, kültürel işaretlerin aktarımını içeren kültürlerarası bir eylem olarak kabul edilmektedir. Farklı kültürler arasında köprü görevini gören çevirmenlerin, uygun bilişsel, kültürel, biçemsel ve dilbilimsel eşdeğerliği bulmak gibi çok önemli ve zor bir görevi bulunmaktadır. Bu görev hedef kitle çocuklar olduğunda daha da zor hale gelmektedir. Bu çalı̧manın amacı, çocuk edebiyatı çevirisinde karşılaşılan sorunlar ve uygulanabilecek stratejiler doğrultusunda, Tolkien'in Letters From Father Christmas kitabındaki kültürel kelime ve ifadelerin Türkçe çevirisinin incelemesini yapmaktır. Lawrence Venuti'nin yerelleştirme ve yabancılaştırma kavramlarının ve Klingberg'in kültürel bağlam uyarlama kategorilerinin çerçevesinde, bu çalışma, çevirmenin stratejilerini ve kararlarını analiz etmektedir ve hedef kültüre aslında oldukça yabancı olan bir bağlamda, çevirmenin hedef okuyucu kitlesi, özellikle de çocuklar üzerinde kaynak metindeki etkiyi yaratıp yaratmadığı konusunda bir tartışma sunmaktadır.

Anahtar sözcükler: kültürel ifadeler; yerelleştirme; yabancılaştırma; çocuk edebiyatı çevirisi; Tolkien; Noel Babadan Mektuplar

\section{AUTHOR BIODATA}

Dr. Gökçen Hastürkoğlu is working as an Assistant Professor at the Faculty of Arts and Sciences, Department of Translation and Interpretation, Atılım University, Ankara, Turkey. After completing her undergraduate degree at Hacettepe University, Translation and Interpretation Department, she earned her MA in the field of English Language and Literature. She completed her $\mathrm{PhD}$ in the field of English Linguistics. Her research interests are translation pedagogy, cognitive linguistics, medical translation, literary translation, and translation criticism. 